\title{
Detection of Weak Radiation Involving Generation and Progress of Water Tree
}

\author{
Takao Kumazawa Member (Chubu Electric Power Co., Inc.) \\ Ryouichi Taniguchi Non-member (Osaka Prefecture University)
}

Keywords : XLPE cable, water tree, bow-tie tree, deterioration, radiation, X-ray, $\gamma$-ray

It is well known that generation and progress of water tree in XLPE cable are remarkably influenced by inorganic impurities. We have investigated the behavior of them in water tree and reported the experimental results as follows: (i) the anomalous increase or decrease in several kinds of inorganic elements was observed in water-treed XLPE sample, (ii) a distinctive relationship was found for the mass numbers for the elements, (iii) the isotopic content of the elements such as $\mathrm{Zn}$ deviated over 6\% from the natural abundance. These results suggest that water tree is concerned with unknown phenomena, e.g., cold fusion or nuclear transmutation in condensed matter.

In order to study the relationship between water tree and these phenomena, we attempted to detect neutron, $\gamma$-ray or X-ray involving generation and progress of water tree in XLPE samples. Figure 1 shows configuration of radiation counter $\left({ }^{3} \mathrm{He}, \mathrm{BF}_{3}\right.$ and $\mathrm{CdZnTe}$ ) and chamber for sheltering from background radiation. The samples, in which fine fibers of absorbent cotton were contaminated as bow-tie tree cores, were immersed in soft or hard water as shown in Fig.2. AC voltage $(\sim 2.7 \mathrm{kV}, 2000 \mathrm{~Hz})$ was applied to the samples for about 1000 hours in test cell. Figure 3 shows typical result of radiation counted by BF3 proportional counter from August 25 to September 14, 2004. Figure 4 shows comparison of energy spectra obtained by $\mathrm{BF}_{3}$ proportional counter just before observing anomalous count and while observing it in August 26, 2004. For the experiments weak and burst-like radiation seemed to be low energy $\gamma$-ray or X-ray was often detected by $\mathrm{BF}_{3}$ and/or $\mathrm{CdZnTe}$ counter. The radiation tended to be detected from the samples in which a lot of water trees were generated by supplying inorganic cations $\left(\mathrm{Mg}^{2+}\right.$ and $\mathrm{Ca}^{2+}$ ) abundantly. These experimental results also suggest that water tree is concerned with unknown phenomena mentioned above.

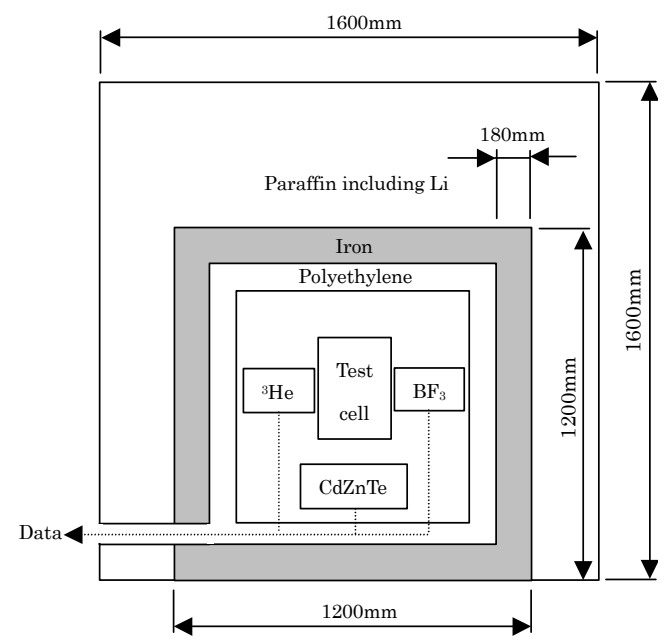

Fig. 1. Configuration of radiation counter and chamber for sheltering from background radiation

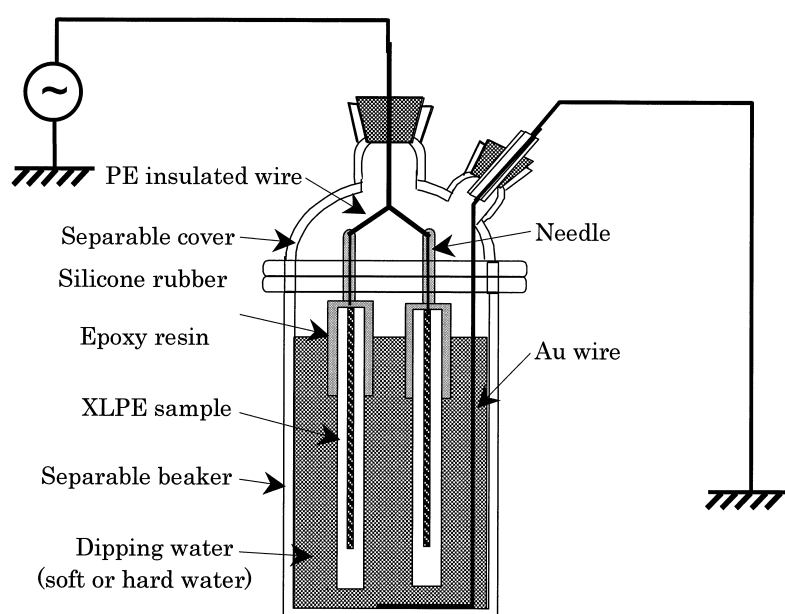

Fig. 2. Test cell for applying voltage

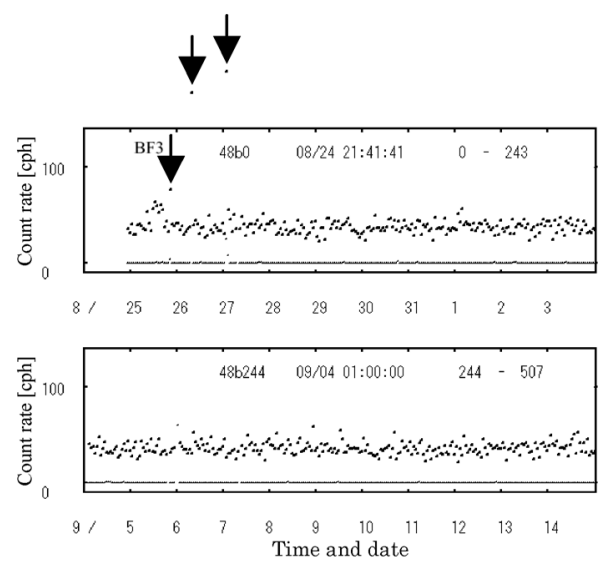

Fig. 3. Typical result of radiation counted by $\mathrm{BF}_{3}$ proportional counter from August 25 to September 14, 2004. The arrows show anomalous count

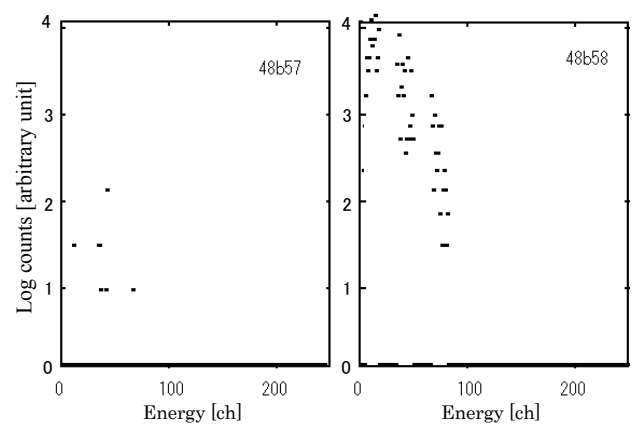

Fig. 4. Comparison of energy spectra obtained by $\mathrm{BF}_{3}$ proportional counter in August 26, 2004. (a) just before observing the anomalous count, (b) while observing it 


\title{
論 文
}

\section{水トリーの発生・進展に伴う微弱放射線の検出}

\author{
正 員 熊澤 孝夫* 非会員 谷口 良一**
}

\section{Detection of Weak Radiation Involving Generation and Progress of Water Tree}

Takao Kumazawa*, Member, Ryouichi Taniguchi**, Non־member

It is well known that generation and progress of water tree in XLPE cable are remarkably influenced by inorganic impurities. We have investigated the behavior of them in water tree and reported the experimental results as follows: i) the anomalous increase or decrease in several kinds of inorganic elements was observed in water treed XLPE samples, ii) a distinctive relationship was found for the mass numbers for the elements, iii) the isotopic content of the elements such as $\mathrm{Zn}$ deviated over $6 \%$ from the natural abundance. These results suggest that water tree is concerned with unknown phenomena e.g., cold fusion or nuclear transmutation in condensed matter. In order to study the relationship between water tree and these phenomena, we attempted to detect neutron, $\gamma$-ray or X-ray involving generation and progress of water tree in XLPE samples. For the experiments weak and burst-like radiation seemed to be low energy $\gamma$-ray or X-ray was often detected by $\mathrm{BF}_{3}$ and/or CdZnTe counter. The radiation tended to be detected from the samples in which a lot of water trees were generated by supplying inorganic cations abundantly.

キーワード：CVケーブル，水トリー，ボウ・タイ状水トリー，劣化，放射線， $\mathrm{X}$ 線， $\gamma$ 線

Keywords : XLPE cable, water tree, bow-tie tree, deterioration, radiation, X-ray, $\gamma$-ray

\section{1. まえがき}

CV ケーブルの主要な劣化形態である水トリーの発生・進 展メカニズムについては，これまでにも多くの仮説が提案 されてきた ${ }^{(1)}$ 。例えば初期においては, 微小突起や異物近傍 の電界集中部で発生するマクスウェル応力, あるいは誘電 泳動力等に基づいた物理的（機械的）なメカニズムが考え られた。また, 近年においては水トリー部の FT-IR 分析に よりカルボニル化合物等の酸化生成物が観測されるに至 り (2)(3), その結果, 不純物として存在する金属イオンの触媒 作用により XLPE（架橋ポリエチレン）が酸化・分子鎖切 断に至るとする化学的なメカニズムも考えられている(4)(5)。 他方, 水トリーの進展と酸化生成物の間には, 一貫した相 関性が見られないとして，XLPE や酸素，イオンが関与す る未知の化学反応が示唆されるとの報告もある(6)。

こうした背景から, 著者らは従来の視点とは一旦切り離

* 中部電力 (株) 技術開発本部 電力技術研究所

干459-8522 名古屋市緑区大高町字北関山 20-1

Electric Power R\&D Center, Chubu Electric Power Co.,Inc.

20-1, Kitasekiyama Ohdaka, Midori-ku, Nagoya 459-8522

** 大阪府立大学 放射線研究センター

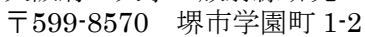

Radiation Research Center, Osaka Prefecture University 1-2, Gakuen-cho, Sakai 599-8570
して, 未知の発生・進展メカニズムが存在する可能性につ いて，様々な実験により考察を進めてきた。その中で最も 注目したのは, 水トリー劣化領域でしばしば検出される不 純物である。とくに無機元素（金属イオン）は，水卜リー

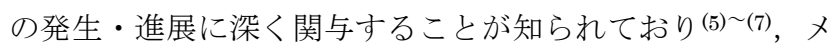
カニズム解明の鍵を握る重要なメッセージが, 何らかの “痕 跡”として託されていることも考えられる。

既に報告(8)(9) したように, 著者らは ppb オーダで不純物を コントロールしながら XLPE 試料に水トリーを発生させ, 試料中に存在する無機元素の濃度や同位体組成比の変化を 詳しく調查した。一連の実験では, 水トリーが発生した試 料において, 質量数が特殊な関係にある金属元素の異常な 増減 (例えば増加した元素は減少した元素より原子番号が 1 ～2 大きく, 微量同位体を除けば質量数は 1 4 程度大きい) や6\%を超える同位体組成比の有意な変化を捉えた。これら の実験結果は, 既知の物理的あるいは電気化学的な反応で は合理的な説明が困難であり，原子核レベルでの何らかの

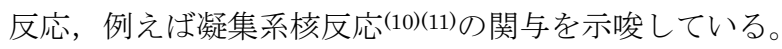

仮にそのような反応が存在・関与するならば，水卜リー の発生・進展時に微弱な放射線 (X 線, $\gamma$ 線あるいは中性子 線）が検出される可能性もある。そこで今回は, バックグ ランド（BG）放射線を効果的に遮蔽する特殊なチャンバー 内で水トリーを発生させながら, 放射線の長時間連続計測 
を行った。この実験では，金属イオンの供給により水トリ 一が多発した XLPE 試料において，バースト的に発生する $\gamma$ 線もしくは X 線と思われる微弱な放射線を検出した。本 論文では，その実験方法ならびに実験結果について述べる とともに, 水トリーの発生・進展と放射線検出の関連性に ついて考察した。

\section{2. 実験方法}

$\langle 2 \cdot 1\rangle$ 試 料 水トリーの発生・進展時に放射線が 検出されるとすれば，極めて微弱であろう。それ故，XLPE 試料にできるだけ多くの水トリーを発生させながら放射線 検出を試みるのが効率的と思われる。絶縁体中の微小異物 から発生するボウ・タイ状水トリー（以下，BTT と略記） は，界面水トリー（Vented tree）と比べて発生密度を容易 に高くできるため，この実験には好都合である。そこで今 回は, 綿糸（繊維屑）を異物として試料に混入させること にした。綿糸は形状が不定形で電界集中を生じやすく，ま た予め電解質を含浸させることにより発生起点から直接イ オンを供給できるため, BTT を大量発生させるのに適して いる。

表 1 に綿糸を用いた BTT 発生核 (Type I および Type II ) の作製方法を示す。まず脱脂綿に, Type I は硬水（通常の ミネラルウォーター）を Type II は軟水（同）を各々含浸さ せ，さらに液体窒素で泠却後，金属研磨紙（\#240）を用い て微粉化した。大きさは概ね数百 $\mu \mathrm{m}$ 以下である。その後, これらの綿糸粉を熱ロールにより XLPE に混練した（刷毛 またはスポイトを用いて分散)。使用した XLPEペレットは 日本ユニカー製 HFDJ-4201 である。なお，綿糸に硬水また は軟水を含浸させた理由は，表 2 に示すように両者に含ま れる一部の金属イオン $\left(\mathrm{Mg}^{2+}, \mathrm{Ca}^{2+}\right)$ の濃度が大きく異なる ことから, 水トリーの発生挙動の違いによって放射線の計 測結果に有意な差が生じることを期待したためである。

これらの綿糸混入済みXLPE と半導電性電極(高圧ケーブ ルの半導電層と同じもの）を用いて，図 1 に示すサンドイ ッチシート試料をプレス成型により作製した。さらに前処 理として，全てのシート試料を $90^{\circ} \mathrm{C}$ 雰囲気に 48 時間暴 露し, 架橋剂分解残渣ならびに水分を除去した（前処理後 の水分量は $5 \mathrm{ppm}$ 未満である)。

$\langle 2 \cdot 2\rangle$ 課電用セル 後述するように試料の課電およ
び放射線の計測はバックグランド放射線を遮蔽する特殊な チャンバー内で連続的に行うため, その間に課電条件が変 わることは好ましくない。そこで試料の課電は, 図 2 に示 す課電用セルを用いて行った。このような密閉系課電にお いては，浸漬水の蒸発・揮散がないため，溶存している金 属イオンの濃度をほぼ一定に保つことができる(12)。ただし， 密閉状態のため, (1)結露等で試料に付着した水滴により閃 絡する恐れがあること, (2)試料の浸水界面部は電界集中が 起こり易く絶縁破壊を引起こす可能性があることから，シ リコーンゴムおよびエポキシ樹脂で当該部分を覆い，防水・ 絶縁補強処理を施した。課電用セルのセッティング方法は, まずセパラブルビーカーに前述の硬水または軟水を注入 し, 次に Type I または Type II の 2 枚の試料を浸漬した後, セパラブルカバーで密閉した。

表 3 に課電条件を示す。試料および浸漬水の違いにより， 合計 4 通りの実験を行った。各試料には，2.6〜 $2.9 \mathrm{kV}$ （実

表 2 硬水および軟水の定量分析結果

Table 2. Result of quantitative analysis for hard and soft water.

\begin{tabular}{|c|c|c|c|c|}
\hline \multirow{2}{*}{ Sample } & \multicolumn{4}{|c|}{ Ion concentration $\left[\mu \mathrm{g} / \mathrm{cm}^{3}\right]$} \\
\cline { 2 - 5 } & $\mathrm{Na}^{+}$ & $\mathrm{Mg}^{2+}$ & $\mathrm{K}^{+}$ & $\mathrm{Ca}^{2+}$ \\
\hline Hard water & 12.1 & 87.5 & 4.18 & 327 \\
\hline Soft water & 12.3 & 8.65 & 6.38 & 13.1 \\
\hline
\end{tabular}

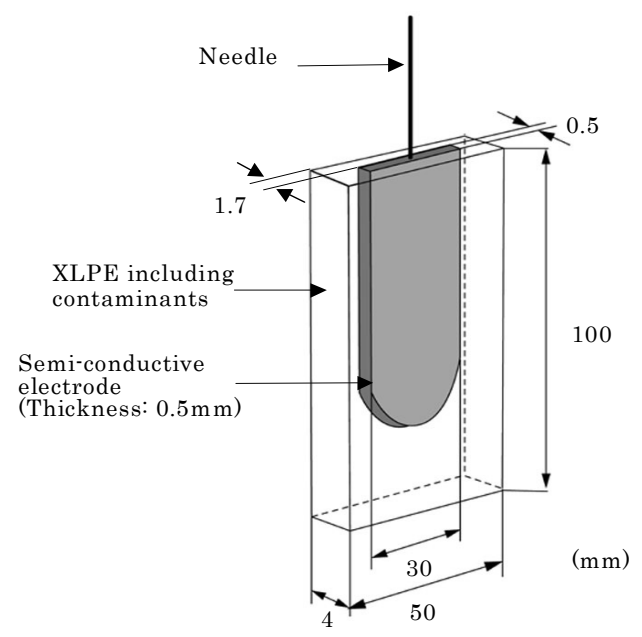

図 1 試料形状

Fig. 1. Construction of XLPE sample.

表 1 BTT 発生核の作製方法

Table 1. Method to make BTT core.

\begin{tabular}{|c|c|c|c|}
\hline Contaminant & Shape & Density $\left(\mathrm{N} / \mathrm{mm}^{3}\right)$ & Process \\
\hline Cotton fiber & 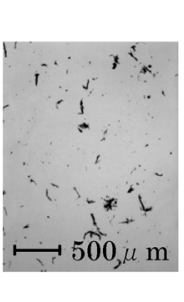 & $6.5 \sim 7.3$ & $\begin{array}{l}\text { (1) Type I : Immersing absorbent cotton in hard water } \\
\text { Type II : Immersing absorbent cotton in soft water } \\
\text { (2) Freezing the absorbent cotton by immersing it in liquid nitrogen } \\
\text { (3) Powdering it using metal grinding paper (\#240) } \\
\text { (4) Mixing the powder with XLPE pellets using brush or syringe and } \\
\text { kneading them by using heated roll machine }\end{array}$ \\
\hline
\end{tabular}


効值), $2000 \mathrm{~Hz}$ の電圧を $800 \sim 1100$ 時間程度印加した。平 均電界ならびに周波数については, $6 \mathrm{kV}$ 級 $\mathrm{CV}$ ケーブルの 一般的な周波数加速劣化試験条件を基に決定した。放射線 の計測時間は概ね 800〜1000 時間である。

$\langle 2 \cdot 3\rangle$ 測定体系 図 3 に測定体系を示す。課電用セ ルの周囲に配置した ${ }^{3} \mathrm{He}, \mathrm{BF}_{3}$ 中性子計数管, $\mathrm{CdZnTeX}$ 線 検出器および電圧・電流モニタ等からの各データは外部の コンピュータに送られる。データの記録は, 放射線データ については 3 系統が独立して働く多重波高分析器で解析し, 1 時間毎にエネルギースペクトルを記録した。また電流，電 圧，温度の各データについては 10 分毎に記録した。

このような放射線計測においては, 電磁ノイズの発生・ 混入を未然に防止することが極めて重要になる。課電用の 高周波電源および課電用セルは, セッティングに何らかの 不具合があると部分放電や微小ギャップ放電により電磁ノ イズが発生する可能性があるため, アルミ管で包みシール ドを施した。さらに，放射線計測回路と他の計測・課電回 路の各駆動電源を別系統にしたほか，接地線を分離するな どの対策を施した。

放射線の計測は図 4 に示すように， 1 辺が $1200 \mathrm{~mm}$ の立 方体の鉄箱（壁面厚は全て $180 \mathrm{~mm}$ ）の中で行い, さらに鉄 箱の内外に中性子遮蔽材（ポリエチレンまたはリチウム入 りパラフィンを充填したパック）を多層配置して，宇宙線

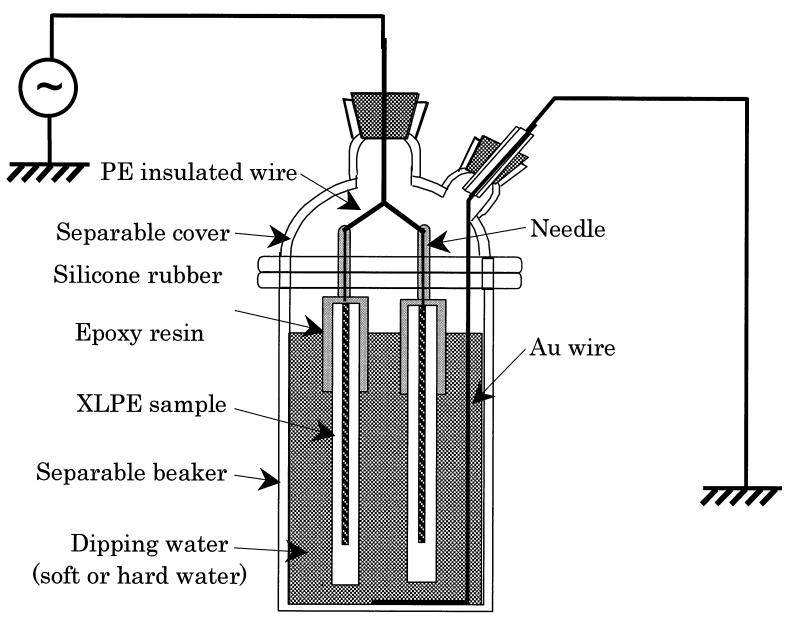

図 2 課電用セル

Fig. 2. Test cell for applying voltage.

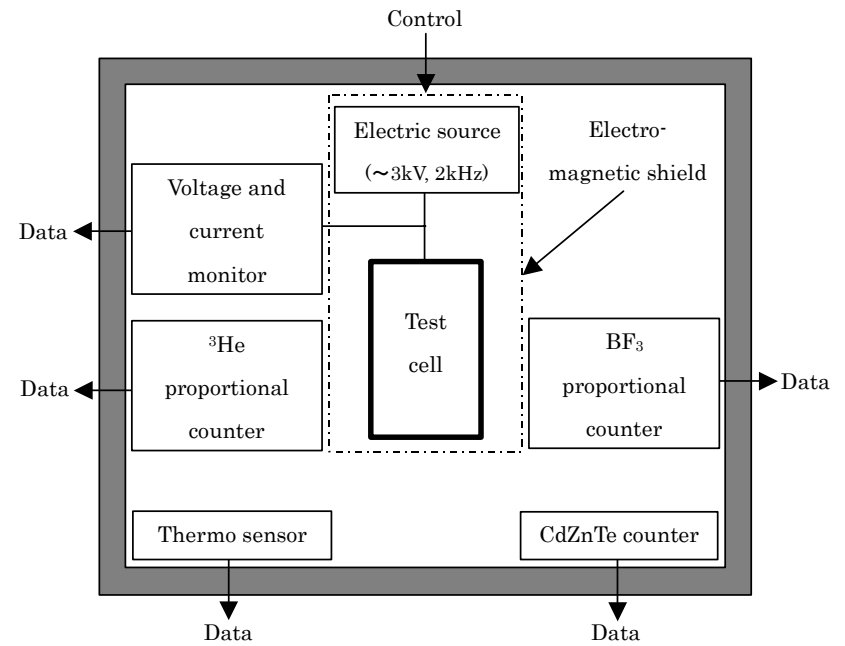

図 3 測定体系

Fig. 3. Measurement system.

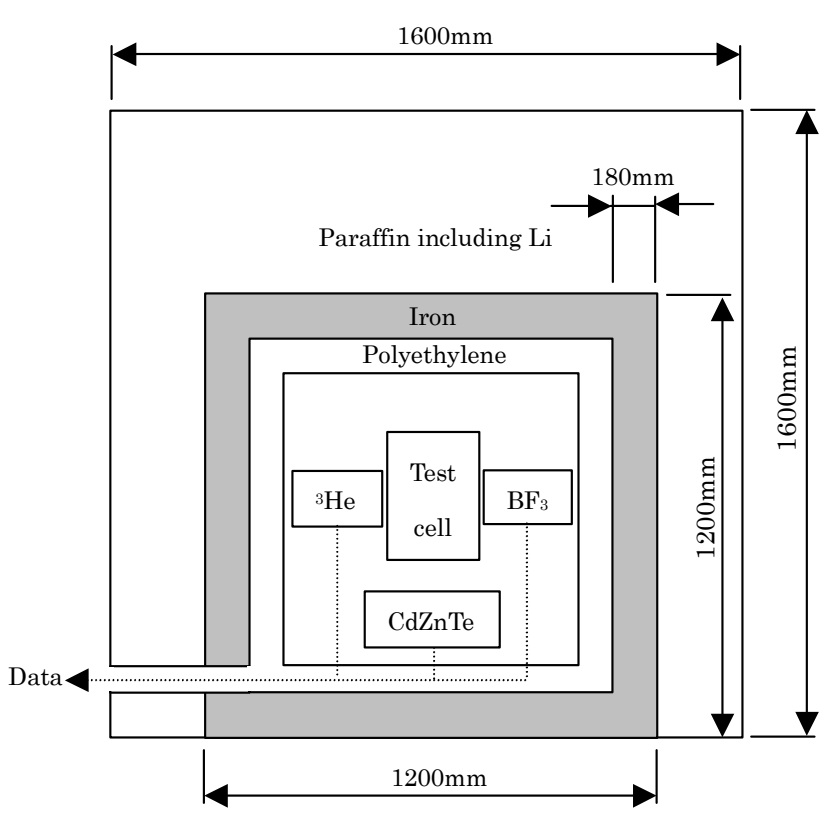

図 4 バックグランド放射線遮蔽用チャンバー

Fig. 4. Chamber for sheltering from background radiation.

表 3 課電条件

Table 3. Condition of voltage application.

\begin{tabular}{|c|c|c|c|c|}
\hline No. & 1 & 2 & 3 & 4 \\
\hline \hline BTT core & Type I & Type II & Type I & Type II \\
\hline Frequency & $2000 \mathrm{~Hz}$ & $2000 \mathrm{~Hz}$ & $2000 \mathrm{~Hz}$ & $2000 \mathrm{~Hz}$ \\
\hline $\begin{array}{c}\text { Applied voltage } \\
\text { (Mean electric } \\
\text { field) }\end{array}$ & $\begin{array}{c}2.9 \mathrm{kV} \\
(1.8 \mathrm{kV} / \mathrm{mm})\end{array}$ & $\begin{array}{c}2.7 \mathrm{kV} \\
(1.7 \mathrm{kV} / \mathrm{mm})\end{array}$ & $\begin{array}{r}2.6 \mathrm{kV} \\
(1.6 \mathrm{kV} / \mathrm{mm})\end{array}$ & $\begin{array}{c}2.7 \mathrm{kV} \\
(1.7 \mathrm{kV} / \mathrm{mm})\end{array}$ \\
\hline Duration time & $787 \mathrm{~h}$ & $997 \mathrm{~h}$ & $1087 \mathrm{~h}$ & $1019 \mathrm{~h}$ \\
\hline Dipping water & Hard water & Hard water & Soft water & Soft water \\
\hline Volume resistivity & $445 \Omega \mathrm{cm}$ at $27^{\circ} \mathrm{C}$ & $441 \Omega \mathrm{cm}$ at $28^{\circ} \mathrm{C}$ & $4900 \Omega \mathrm{cm}$ at $28^{\circ} \mathrm{C}$ & $5050 \Omega \mathrm{cm}$ at $16^{\circ} \mathrm{C}$ \\
\hline
\end{tabular}




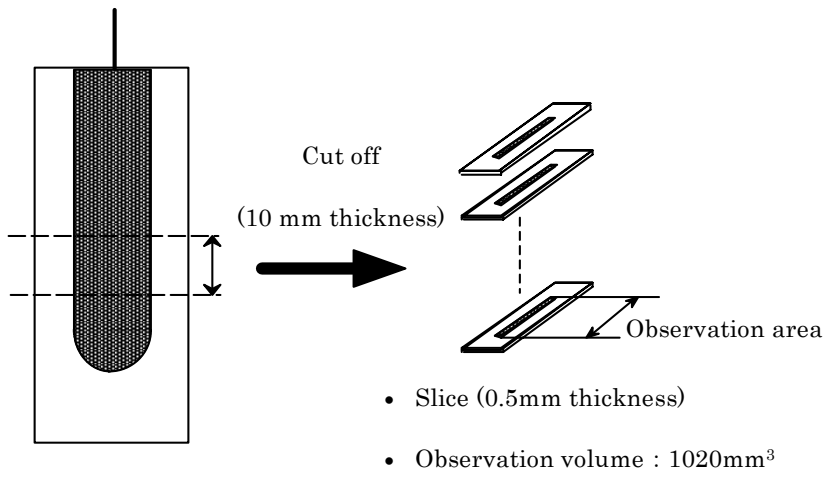

図 5 BTT 観察用試料片の採取方法

Fig. 5. Method to collect sample for BTT observation.

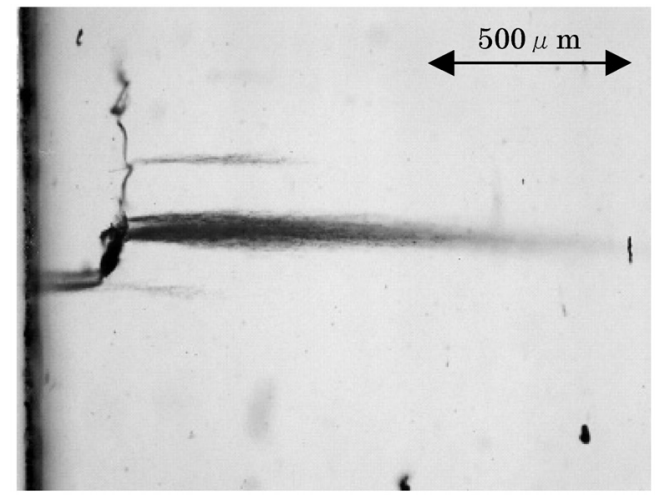

図 6 BTT 観察結果の一例(No. 1)

Fig. 6. Typical result of BTT observation (No.1). BTT length: $1375 \mu \mathrm{m}$

表 4 BTT 観察結果および放射線計測結果

Table 4. Results of BTT observation and radiation counting.

\begin{tabular}{|c|c|c|c|c|c|c|c|c|c|}
\hline \multirow[b]{2}{*}{ No. } & \multirow[b]{2}{*}{$\begin{array}{l}\text { BTT } \\
\text { core }\end{array}$} & \multirow[b]{2}{*}{$\begin{array}{l}\text { Dipping } \\
\text { water }\end{array}$} & \multicolumn{3}{|c|}{ BTT observation } & \multicolumn{3}{|c|}{ Average count rate $\left(^{*}\right)$} & \multirow[b]{2}{*}{$\begin{array}{c}\text { Frequency of } \\
\text { anomalous } \\
\text { count }\end{array}$} \\
\hline & & & $\begin{array}{l}\text { Number } \\
{\left[\mathrm{N} / \mathrm{cm}^{3}\right]}\end{array}$ & $\begin{array}{c}\text { Average } \\
\text { length } \\
{[\mu \mathrm{m}]}\end{array}$ & $\begin{array}{c}\text { Maximum } \\
\text { length } \\
{[\mu \mathrm{m}]}\end{array}$ & $\begin{array}{c}\mathrm{BF}_{3} \\
\text { Proportional } \\
\text { counter } \\
{[\mathrm{cph}]} \\
\end{array}$ & $\begin{array}{c}{ }^{3} \mathrm{He} \\
\text { Proportional } \\
\text { counter } \\
\text { [cph] } \\
\end{array}$ & $\begin{array}{c}\text { CdZnTe } \\
\text { counter } \\
\text { [cph] }\end{array}$ & \\
\hline 1 & Type I & $\begin{array}{l}\text { Hard } \\
\text { water }\end{array}$ & 1232 & 346 & 1400 & $36.9 \pm 6.3$ & $41.6 \pm 6.4$ & Failure & Low \\
\hline 2 & Type II & $\begin{array}{l}\text { Hard } \\
\text { water }\end{array}$ & 709 & 308 & 1125 & $67.5 \pm 60.9$ & $40.5 \pm 6.6$ & $12.4 \pm 4.7$ & High \\
\hline 3 & Type I & $\begin{array}{c}\text { Soft } \\
\text { water }\end{array}$ & 840 & 373 & 1375 & $36.4 \pm 6.4$ & $41.9 \pm 6.7$ & $12.2 \pm 4.0$ & Middle \\
\hline 4 & Type II & $\begin{array}{c}\text { Soft } \\
\text { water }\end{array}$ & 321 & 299 & 1225 & $35.2 \pm 6.6$ & $41.2 \pm 6.7$ & $12.2 \pm 3.5$ & None \\
\hline BG & - & - & - & - & - & $38.1 \pm 7.7$ & $42.8 \pm 6.5$ & $13.0 \pm 3.6$ & None \\
\hline
\end{tabular}

$\left.{ }^{*}\right)$ The numbers behind \pm show standard deviation.

に由来する $\gamma$ 線と中性子の各バックグランドを同時に遮蔽 するようにした。その結果， $\gamma$ 線バックグランドを約 $1 / 30$ に, 中性子バックグランドを約 $1 / 6$ にそれぞれ減少させるこ とができた。

〈2.4〉試料の観察 図 5 にBTT 観察用試料片の採取 方法を示す。まず， 2 枚の試料のいずれか一方の BTT 発生 部分(平等電界部)から，観察体積が一定(約 $1020 \mathrm{~mm}^{3}$ ) にな るように切り出し，これを $0.5 \mathrm{~mm}$ 厚にスライスした後，ク リスタルバイオレット溶液で煮沸染色した。この試料片に ついて, 光学顕微鏡により $100 \mu \mathrm{m}$ 以上の BTT を観察した。

\section{3. 結果および考察}

〈3·1〉試料の観察 図6にBTT 観察結果の一例を示 す。綿系は不定形であるため，BTT は通常見られるような シンメトリックな形状にはならず, 大部分は電界の単方向 のみに進展する特徴的なものであった。

〈3·2〉 計測結果の概要 表 4 にBTT の発生状況と放 射線計測結果を対比して示す。BTT の発生数については, No.1 が最多, No.4 が最少で, No.2 と No.3 はほぼ中間の水 準となっている。また平均伸びと最大伸びについては，い ずれも BTT 発生核が Type I の No.1 と No.3 が大きく, Type
II N No.2 と No.4 が小さい。総じて BTT の発生・進展は,

No. $1>$ No. $2 \fallingdotseq$ No. $3>$ No. 4

の順で顕著である。これらの結果から, 少なくとも綿糸の 含浸もしくは試料の浸漬のいずれかに金属イオンの多い硬 水を用いると, BTT の発生・進展が促進され易いことがわ かる。特に綿糸の含浸に用いた場合は効果が大きく，これ は含浸処理によって BTT 発生核から直接イオンが供給され たためと考えられる。典型的な例として, No.1のみ課電開 始から 20 日後に長大な BTT が原因と思われる試料の貫通 破壊が起きた。ただし電圧・電流モニタの記録から, これ 以降も微小な放電を伴いながら課電が継続されたと推察さ れ，電気分解によるミネラル成分の析出が見られた。

一方，放射線の計測結果については，No.4 を除いて頻度 の差はあるものの, いずれも異常計数（主としてバースト 的な計数増加）が観測されている。3 種類の検出器による同 時計測にもかかわらず，その殆どは $\mathrm{BF}_{3}$ 検出器でのみ捉え られていた。前述のようにNo.4 は水トリーの発生・進展が 最も緩慢であるが, 結果的に異常応答が観測されない唯一 の実験となったことは非常に示唆的である。なお, CdZnTe 検出器は素子の冷却系が不安定になることがあり, No.1 で 
は残念ながら正確な計測ができなかった。

〈3.3〉放射線計数とエネルギースペクトル＼cjkstart図 7 に, 異常計数が最も多かったNo.2における $\mathrm{BF}_{3}$ 検出器の放射線 計測結果の一部を示す。代表的な異常計数 (2004 年 8 月 25 日〜27 日）を矢印で表示した。また，図 8 にNo.3におけ る $\mathrm{BF}_{3}$ 検出器の放射線計測結果を示す。同様に異常計数 (同 10 月 25 日）を矢印で表示した。これらの異常計数は，い ずれも課電直後から数日の間に観測されているが，概して 課電初期に観測され易い傾向があった。

図 9 に, 8 月 26 日に観測された $\mathrm{BF}_{3}$ 検出器の異常計数時 におけるエネルギースペクトルを, その直前のものと比較 して示した。図 10 には 10 月 25 日に観測された異常計数時 におけるエネルギースペクトルを同様にして示した。ただ
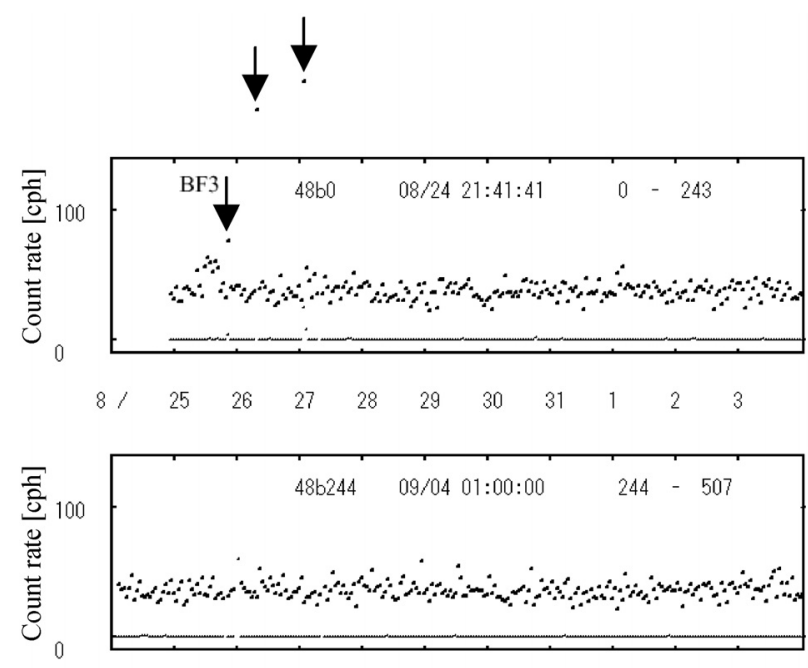

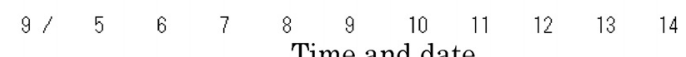

図 $7 \mathrm{BF}_{3}$ 検出器による放射線計測結果 (No.2)

Fig. 7. Result of radiation counted by $\mathrm{BF}_{3}$ proportional counter (No.2). The arrows show anomalous count.

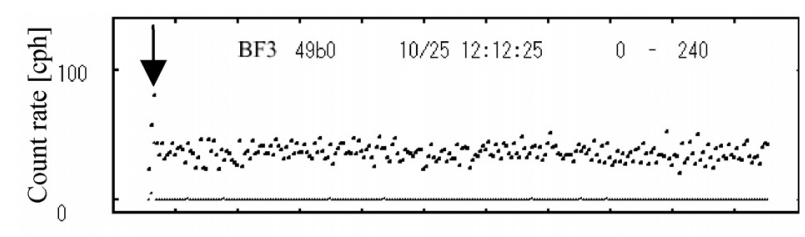

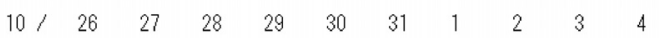

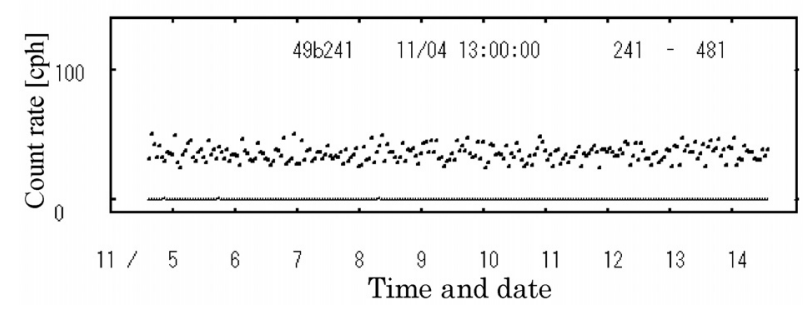

図 $8 \mathrm{BF}_{3}$ 検出器による放射線計測結果 (No.3)

Fig. 8. Result of radiation counted by $\mathrm{BF}_{3}$ proportional counter (No.3). The arrow shows anomalous count.
し，計数管の劣化を考慮して標準線源によるキャリブレー ションは未実施のため, 今回は相対比較とした。いずれの スペクトルも異常計数直前ではほぼ正常であるが, 異常計 数時には比較的高エネルギーの領域で計数が増大している (低エネルギーになるほど電磁ノイズの可能性が高い)。こ の領域に着目すると, 図 9 のケースでは中性子を検出して いる可能性も否定できない。ただし, ${ }^{3} \mathrm{He}$ 検出器では異常計 数が観測されていないことから，同時計数による確認には 至らなかった。

なお, $\mathrm{CdZnTe}$ 検出器については, 中性子の検出は原理上 困難である（X 線または $\gamma$ 線の検出が可能）。

他方, 図 10 のケースは図 9 と比べてやや低エネルギー領 域の計数増加が見られることから, 中性子ではなく $\gamma$ 線も しくは X 線を検出している可能性が考えられる。仮に $\gamma$ 線 (X 線) であるとすると, ${ }^{3} \mathrm{He}$ 検出器は $\mathrm{BF}_{3}$ 検出器よりも感 度が低いため, 異常計数が観測され難くなる。そこで, $\mathrm{CdZnTe}$ 検出器のエネルギースペクトルに着目した。図 11 に, 図 10 と同時刻に得られた CdZnTe 検出器のエネルギー スペクトルを示す。異常計数直前ではほぼ正常であるが, 異常計数時には $100 \mathrm{ch}$ 近傍のエネルギー領域で計数が大き く増加しているのがわかる。これらの結果から, $\mathrm{BF}_{3}$ 検出器 と $\mathrm{CdZnTe}$ 検出器の双方で同時刻に同一の現象, 寸なわち $\gamma$ 線（X線）を捉えていた可能性が高い。

ところで, 電気トリーでは発生・進展時に部分放電を伴 うほか, 発生の前駆段階に発光現象（可視領域にスペクト ルのピークを形成, 部分放電発生時は紫外領域にピークを 形成）が観測される(13)。水トリーでは同様の報告はないが, これは, 低電界で発生・進展する水トリーの場合, 先端の 電界集中部での電荷の注入や加速, 再結合等が実質的に起

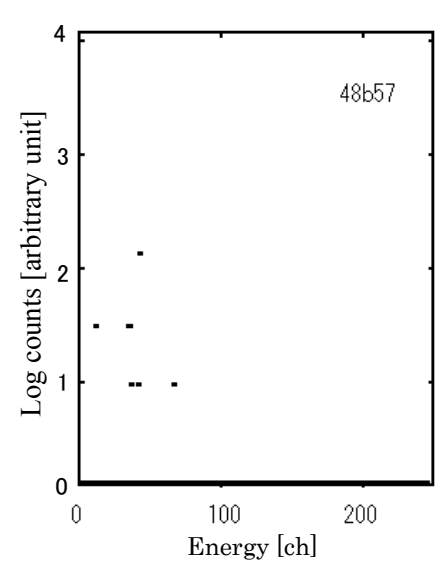

(a)異常計数直前

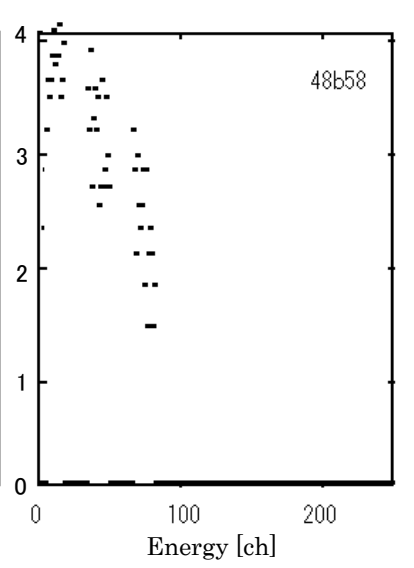

(b) 異常計数時
図98月 26 日に観測された $\mathrm{BF}_{3}$ 検出器の 異常計数とその直前の計数に対応する

$$
\text { エネルギースペクトルの比較 }
$$

Fig. 9. Comparison of energy spectra obtained by $\mathrm{BF}_{3}$ proportional counter in August 26, 2004. (a) just before observing the anomalous count, (b) while observing it. 


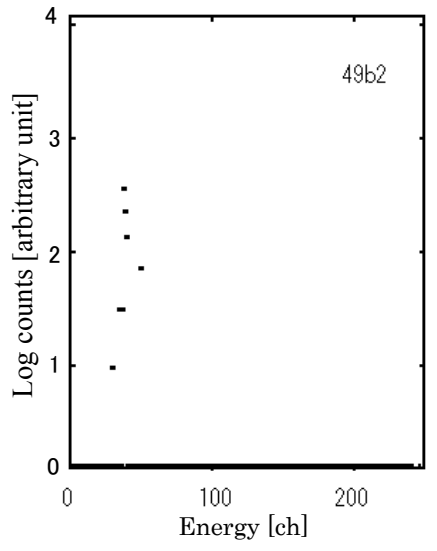

(a) 異常計数直前

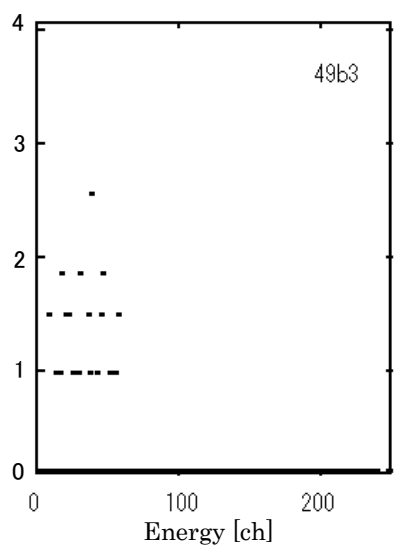

(b) 異常計数時
図 1010 月 25 日に観測された $\mathrm{BF}_{3}$ 検出器の

異常計数とその直前の計数に対応する エネルギースペクトルの比較

Fig. 10. Comparison of energy spectra obtained by $\mathrm{BF}_{3}$ proportional counter in October 25, 2004. (a) just before observing the anomalous count, (b) while observing it.

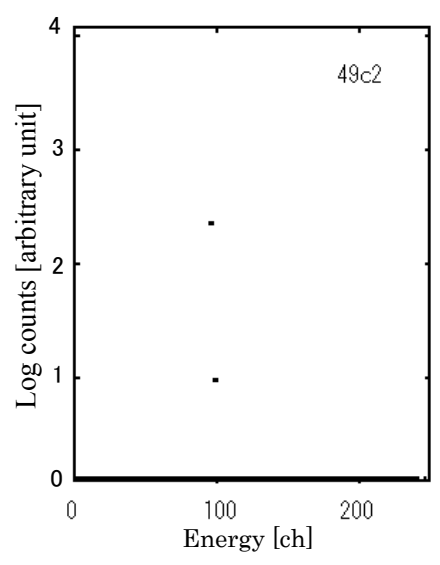

(a) 異常計数直前

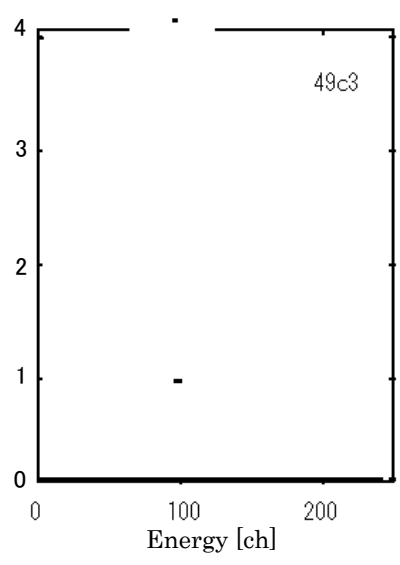

(b)異常計数時
図 1110 月 25 日に観測された CdZnTe 検出器の

異常計数とその直前の計数に対応する

$$
\text { エネルギースペクトルの比較 }
$$

Fig. 11. Comparison of energy spectra obtained by CdZnTe counter in October 25, 2004. (a) just before observing the anomalous count, (b) while observing it.

きないためと考えられる。その意味では，比較的穏やかな 劣化現象と言えよう。しかしながら $\gamma$ 線 (X 線) の放射を伴 うとすれば，観測されるフォトンのエネルギーは電気トリ 一の場合と比べて桁違いに大きいため, 非常に激しい劣化 現象と言う一面も併せ持つことになる。しかも既知の物理 的あるいは電気化学的な反応では十分な説明が難しい。す なわち, $\gamma$ 線は原子核に基因 ( $\mathrm{X}$ 線は原子に基因) するため, 従来の分子レベルのアプローチのみでは水トリーの発生・ 進展メカニズムの解明が困難になってくることが予想さ
れる。

既に報告(8)(9) したように水トリー発生試料で観測された 無機元素の異常な増減や同位体組成比の有意な変化など は, 水トリーの発生・進展過程で生じた原子核レベルの “副 産物”の可能性がある。今回観測された放射線の異常計数 は散発的かつバースト的ではあるが，この可能性を支持し ているように見える。前述のように $\gamma$ 線は原子核内部の工 ネルギー遷移の過程で, また X 線は軌道電子のエネルギー 遷移の過程でそれぞれ発生する。仮に何らかの反応により $\mathrm{MeV}$ オーダの荷電粒子が生成されたとすると, これが軌道 電子と衝突し減速する過程で特性X線が生じるため, その 検出は原子核レベルの反応を裏付ける有力な証拠になると 考えられている(10)。

今回の実験では, 表 4 に示したようにBTT が発生しても 異常計数が観測されないケースもあった。著者らは, これ までに 1000 時間を超えるバックグランド（BG；課電用セ ルが未課電状態にあるかもしくは設置されていない状態） の測定を適宜実施してきたが，異常計数は全く観測されて いない。このことから, 異常計数は水トリーの発生・進展 を必要条件 (勿論, 十分条件ではない) として観測される のではないかと考えている。ただし, 課電初期に観測され 易いといった点に関しては, 現時点において理由は不明で ある。

一方, 発生する放射線は極めて微弱であるから, XLPE の分子鎖切断を進行させるものとは考え難く (勿論, 生体 には無害である), 同様に “副産物” の一つと考えれば合理 的である。すなわち, 水卜リーの発生・進展に不可欠な工 ネルギーを直接供給するような, 原子核レベルの何らかの 反応による副次的な生成物と考えるわけである。このよう に, 原子・原子核レベルで水トリー劣化現象を観測すると 多くの興味深い実験データが得られることから, 何らかの 核的な反応が関与している可能性が示唆される。例えば, $0.1 \mathrm{MV} / \mathrm{mm}$ オーダの局所高電界中を運動する金属イオンと XLPE 分子中の極めて豊富な水素原子が関与した未知の反 応が考えられる(12)。最近では, 水卜リーが発生した課電後 の XLPE 試料やそれを浸漬した水溶液が放射化されたこと を示唆する $\gamma$ 線の計測データも得られている(14)。これにつ いては，別の機会に詳しく報告したいと思う。

〈3.4〉電磁ノイズの影響放射線計測時にシステム に電磁ノイズが混入すると, 放射線の計数值が増加するこ とがあるが, この場合, 低エネルギー領域が強調された（持 ち上がった）エネルギースペクトルとなる。これが顕著な 場合は, S/N が悪化して真の異常計数が埋もれてしまい, 現象が非常に観測し辛くなる。そのため実験方法で述べた ように, 電磁ノイズの抑制に十分な注意を払った。この効 果は, 結果的に試料の絶縁破壊が生じた No.1 の実験で評価 することができた。

図 12 に, 試料が 8 月 3 日に絶縁破壊する直前・直後の $\mathrm{BF}_{3}$ 検出器と ${ }^{3} \mathrm{He}$ 検出器の放射線計測結果を示す。既に述 べたように, これ以降も微小な放電を伴いながら課電が継 


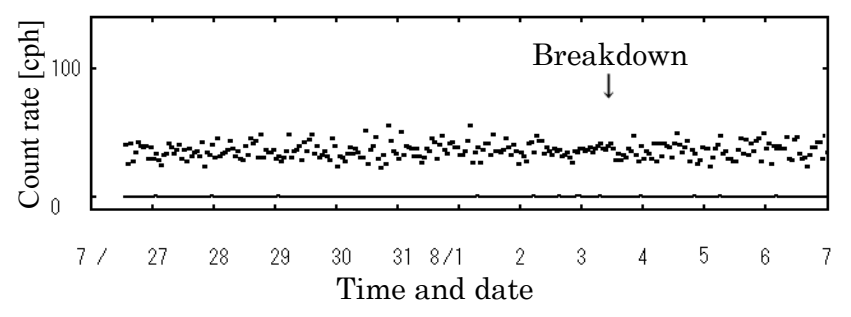

(a) $\mathrm{BF}_{3}$ proportional counter

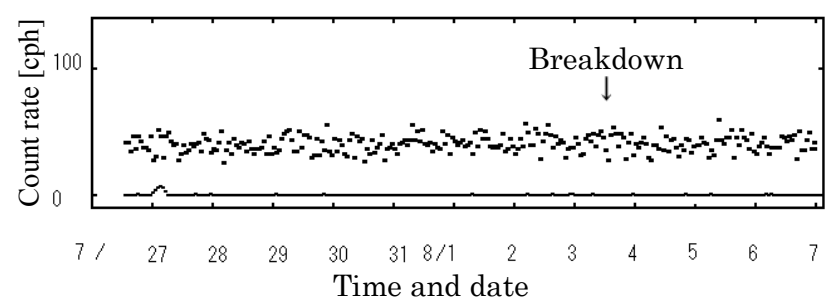

(b) ${ }^{3} \mathrm{He}$ proportional counter

図 12 試料の破壊前後における放射線計測結果（No.1）

Fig. 12. Results of radiation counted by $\mathrm{BF}_{3}$ and ${ }^{3} \mathrm{He}$ proportional counter before and after breakdown of sample (No.1).

続されたと推察される。この場合, 放電に伴う電磁パルス の輻射は避けられず，一部が測定体系に混入する可能性は 否定できない。しかしながら，同図に示すように不自然な 計数増加等は何ら見られないため, 電磁ノイズ対策が十分 に機能していたことが実証された。

\section{4. あとがき}

$\mathrm{CV}$ ケーブルの主要な劣化形態である水トリーの発生・進 展メカニズムについては, 依然として不明な点が多い。今 回は新たな視点に立ってそのメカニズムを検討するため,

XLPE 試料に水トリーを発生させながら放射線の連続測定 を試みた。その結果, 以下の知見が得られた。

(1) $\mathrm{BF}_{3}$ 中性子検出器ではバースト的に現れる異常計 数を観測したが, ${ }^{3} \mathrm{He}$ 中性子検出器では全ての試料で異常計 数は観測されなかった

（2） CdZnTeX線検出器では同時刻にエネルギースペク トルの変化を観測した

(3) $\gamma$ 線に対する感度は ${ }^{3} \mathrm{He}$ 検出器よりも $\mathrm{BF}_{3}$ 検出器 の方が高いこと, $\mathrm{CdZnTe}$ 検出器により同時計測したことか ら検出したのは $\gamma$ 線である可能性が高い

（4）異常計数は, イオンの大量供給により多数の水卜リ 一が発生した試料において, 課電初期に観測されやすい傾 向があった

（5）水トリーの発生・進展時に原子核レベルの未知の反 応が関与している可能性が示唆された

今後は, 水トリーの発生・進展時における放射線計測デ 一タをさらに蓄積するとともに，エネルギースペクトルを 詳しく分析して，放射線の起源・発生メカニズム等につい て検討する予定である。

最後に, 本実験にご協力頂いたタツタ電線（株）の中川渡
氏（電線総合技術センターに出向中）に感謝いたします。 (平成 17 年 11 月 25 日受付, 平成 18 年 10 月 23 日再受付)

\section{文献}

（1）絶縁材料・インパルストリーイング調査専門委員会:「有機絶縁材料 における水トリーについて(3)-ボウタイ状水トリーー」, 電気学会 技術報告，I 部，No.134 (1982)

(2) R. Ross and J. J. Smit: "Composition and Growth of Water Trees in XLPE", IEEE Trans. EI, Vol.27, No.3, pp.519-531 (1992)

（3）武藤秀二・丸山義雄 :「水トリ一の化学的特性の検討」, 平成 6 年電 気学会全国大会, No.399 (1994)

(4) H. Ohno, G. Katsuta, I. Kajiki, K. Kato, Y. Sakaguchi, and G. Tanimoto : "A Study on Electrical Deterioration and Quality Control of XLPE Cable", Proc. 4th Annual Conf. Power \& Energy Society, IEE Japan, No.44 (1993-8) (in Japanese) 大野博伸・勝田銀造・加治木勇・加藤賢司 $\cdot$ 坂口義則 $\cdot$ 谷本 元: $「 \mathrm{CV}$ ケーブルの絶縁劣化と品質管理に関する一考察, 平成 5 年電気学会 電力・エネルギー部門大会, No.44 (1993-8)

(5) Z. Fan, H. Miyata, I. Fujimoto, and T. Niwa : "Relation between Oxidation ability of Various Ion and Growth of Water Trees", The Papers of Technical Meeting on Dielectrics and Electrical Insulation, IEE Japan DEI-97-57 (1997)

(6) A. T. Bulinski, J. P. Crine, B. Noirhoome, R. J. Densley, and S. Bamji : "Polymer Oxidation and Water Treeing", IEEE Trans. DEI, Vol.5, No.4, pp.558-570 (1998)

(7) T. Kumazawa, H. Date, W. Nakagawa, and H. Tsurumaru : "Characteristic of Bow-tie Water Tree in XLPE Including Contaminants (3)”, 1999 National Convention Record IEE Japan, No.374 (1999-3) (in Japanese)

熊澤孝夫・伊達 博・中川 渡・鶴丸秀一:「ボウタイ状水トリーの 特性について (その 3)」, 平成 11 年度電気学会全国大会, No.374 (1999-3)

(8) T. Kumazawa, W. Nakagawa, and H. Tsurumaru : "A Syudy on Behavior of Inorganic Impurities in Water-tree", IEEJ Trans. $F M$, Vol.124, No.9, pp.827-836 (2004-9) (in Japanese) 熊澤孝夫・中川 渡・鶴丸秀一: 「水トリー中の無機不純物の挙動に 関する一考察」, 電学論 A, 124, .9, pp.827-836 (2004-9)

(9) T. Kumazawa, W. Nakagawa, and H. Tsurumaru : "A Syudy on Behavior of Inorganic Impurities in Water Tree", Electrical Engineering in Japan, Vol.153, No.2, pp.1-13 (2005-11)

（10）高橋亮人 - 沼田博雄 - 山田 弘 - 岩村康弘 - 大森唯義 - 水野忠彦 秋本 正 : 個体内核反応研究, No.1, 工学社 (1999-12)

(11) 高橋亮人：「凝集体内核融合の研究」, 核データニュース(日本原子力 研究所核データセンター), No.75, pp.38-54 (2003)

(12) T. Kumazawa, W. Nakagawa, and H. Tsurumaru : "Influence of Water and Ion Diffusion on Generation and Progress of Bow-tie Tree", IEEJ Trans. FM, Vol.125, No.10, pp.828-834 (2005-10) (in Japanese)

熊澤孝夫・中川 渡・鶴丸秀一:「ボウ・タイ状水トリーの発生・進 展に与える水分とイオン拡散の影響」, 電学論 $\mathrm{A}, 125,10$, pp.828-834 (2005-10)

(13) K. Kaminaga, N. Yoshifuji, T. Uozumi, J. Yorita, Y. Inoue, and S. Fukunaga : "Study on Deterioration Mechanism of XLPE Cables", T. IEE Japan, Vol.117-A, No.1, pp.35-41 (1997-1) (in Japanese)

神永建二・吉藤直久 - 魚住 剛 - 依田 潤 - 井上喜之 - 福永定夫 : $\lceil\mathrm{XLPE}$ ケーブルの劣化メカニズムの基礎検討」, 電学論 A, 117, 1 , pp.35-41 (1997-1)

(14) T. Kumazawa and R Taniguchi : "Measurement of Radiation Emission Associated with Growth of Water Trees (5) Induced Radio-activities in Water-treed sample ", Proc. 2006 Annual Meeting of the Atomic Energy Society of Japan, K16 (2006-3) (in Japanese)

熊澤孝夫・谷口良一:「水トリー発生に伴う放射線の計測(5); 水卜 リー劣化試料中の微弱放射性核種の測定」, 日本原子力学会 2006 年 春の年会, K16 (2006-3) 


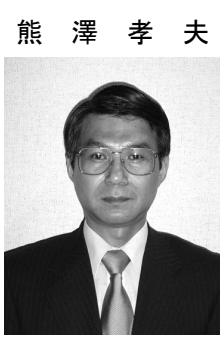

（正員） 1958 年 6 月 26 日生まれ。1983 年 3 月岐阜大学大学院工学研究科修士課程修了。同 年 4 月中部電力株式会社に入社。現在，同社電 力技術研究所にて高分子絶縁材料の劣化様相 解明や電力ケーブル・機器の劣化診断に関する 研究に従事。1995 年 3 月岐阜大学大学院工学 研究科博士後期課程修了。工学博士。日本原子 力学会員。2006 年電気学会論文賞受賞。
谷口 良 - (非会員) 1955 年 3 月 28 日生まれ。大阪大学 大学院工学研究科原子力工学専攻修士課程終 了。現在, 大阪府立大学産学官連携機構放射線 研究センター助教授, 電子線加速器の維持管 理, 開発に従事。研究では, 放射線計測, 特に 放射線画像計測, 大線量計測, 微弱放射線計測 を得意とする。博士 (工学), 日本原子力学会 員, 応用物理学会員, 日本非破壊検查協会員。 